Studia Anglica Posnaniensia 45/1, 2009

(C) School of English, Adam Mickiewicz University, Poznań, Poland

doi: 10.2478/v10121-009-0011-8

\title{
[UN]SUCCESFUL “METABOLIZATION" OF THE NORTHERN IRISH WAR: THE POST-TROUBLES TRAUMA IN GLENN PATTERSON'S WRITING
}

RYSZARD BARTNIK

Adam Mickiewicz University, Poznań

\begin{abstract}
Northern Irish literature of the last decade illustrates an arduous effort of the Ulster men to break down the walls of political and cultural partition. Yet, even though the Northern Irish community tends to present itself in terms of a variety of images, the ultimate impression is that the recent novelistic and critical productions resonate with past antagonisms and the post-Troubles trauma. It is so since the North, as many a scholar indicates, is as if fated to continually recompose its past. This paper then, set against the background of the civil war experiences, discusses Glenn Patterson's excavation of individual and collective memories which prove that the dead are constantly materializing in today's Northern Irish reality. Hence, Glenn Patterson's accumulation of voices by means of which the author ponders over the politics of memory and imparts knowledge of the characters who, on a long journey out of the darkness into the space of light, find some vestiges of the old conflicts still echoing and rather difficult to hush up.
\end{abstract}

The aim of this article is to discuss Glenn Patterson's writing set as it is against the backdrop of the Northern Irish conflict; yet an adjoining question which resonates here is to what extent a post-Troubles Northern Irish novelist is still inclined to write about the Protestant-Catholic war as well as its consequences, and whether he is capable of abstaining whatsoever from thematizing this issue. As some believe, a pressing need for a new imaginative narrative drifting away from the revolutionary turmoil Northern Ireland found itself in is a fact, and as such must be acknowledged as well as endorsed. Interestingly, Nadine Gordimer in her book Living in hope and history, though in a different cultural setting, takes a critical stance on the above assumption. She does admit that a new political context, by and large, has the potential to encourage, even compel writers to release themselves from the imposed obligation to debate over reality 
which, seemingly, is no longer the reality of war. To write "imaginatively", as she indicates, is often considered a prerequisite for grasping "the fullness of human life" (Gordimer 2000: 13). Gordimer, however, finds this argumentation hard to comply with.

She perceives authorship through engagement with either political or cultural issues. According to her, the writer cannot eschew touching upon the complexity of the time and place in which he/she happens to exist. Given her viewpoint, engagement is not "set apart from the range of the creative imagination; [nonetheless], comes from within the writer ... living in history" (2000: 31). As she emphasizes, everyone must respond to their "cultural matrix" since books are created from "... life experience" that takes into account "political, economic or social" determinants (2000: 41). Apparently, Northern Irish literature has been stigmatized by such socio-political conditioning, namely the Troubles. In confirmation of Gordimer's stance, Glenn Patterson claims that it is of course fiction he gives considerable attention, still a fictional construct must stem from the cultural and political background he recognizes as his own (Patterson interviewed by Hogg, 2004). My intention here, thus, is to use Patterson's texts Lapsed Protestant and That which was as examples displaying his interest in the Northern Irish consciousness as still submerged in a deep state of national strife.

Harvey Cox, for that matter, points out that it would be inaccurate to state that due to the peace settlements the Northern Irish war is over. Since there is no mention of "a great act of peace and reconciliation [which has] wind[ed] up the war", it would be more preferable to say that the conflict, being a result of the received mind-set, still flickers in the North, only its character has changed from military to "political" (2007: 159). Individuals in Ulster do not seem to have ceased to live too local a life in the world of resonant prejudices; wherein identities still have an antagonistic flavor and political standpoints are characterized by ideological insularities anchored to the troubled past. Their perspective runs parallel, however negatively, to the one got by Walter Benjamin's "Angel of history". The Angel, as described by the philosopher, pushed forward by wind symbolizing "progress" and change, has his back turned towards the future; simultaneously, unable to turn around, is enslaved by the past facing "ruins and catastrophe" (Benjamin 1996: 415). This is the experience which defines the Northern Irish mentality; experience which Nick Laird - another Northern Irish writer - claims, has not been as yet "successfully metabolized" (Laird 2006: 3). ${ }^{1}$ What has not been, as he says, metabolized are memories of

1 Laird, though of a different personal history and religious background, does acquiesce to opinions that the Northern Irish frame of mind manifests itself by "suffer[ing] from the burden of a faultless memory" (2006: 13). 
the Troubles as marked by killings, bombings, disappearances and intercultural hostilities. Hence, his narrative as well as Patterson's is condemned to a fictional recounting of "that which was".

Patterson, analogically to Laird, could say that the nightmare of the past has been built up within him to such an extent that its obliteration is doubtful. Had he attempted to circumvent referential writing, he would have not succeeded. In Lapsed Protestant ${ }^{2}$ Patterson - almost dejectedly - explains: "I have often written what I think will be my last word on the subject. Like many another thing, however, the subject does not go away" (Patterson 2006: 20). In opposition to his father, ${ }^{3}$ Patterson reckons that there is a point in dwelling on what went before; moreover, this seems habitual if not compulsive. Warding off critical voices on the imperfection of Northern Irish writing as originating "out of existence", here meaning the Troubles, Patterson lays emphasis on the fact that "[w]e draw heavily on the communities ... which nurtured us, and even when we write out of a desire to inform, in the broadest sense, it is hard sometimes not to feel, in the narrowest sense, like an informer" (2006: 181). As he elaborates later on, his prose writing does not exist "in a vacuum" but is set in a welldefined "historical, political and geographical" framework. Therefore, Patterson's narratives remain informative in a more restricted Northern Irish sense of the political, cultural and military confrontation.

Were it not for the conflict, we would not have had Mark Ryan saying in 1994 that for almost three decades " ... every aspect of life in Northern Ireland was organized around the reality of war" (1994: 141). This reality, in spite of everything, still overshadows Northern Ireland along with its literary voices. After the cessation of fire and - four years later - the peace settlements, Ryan feared an unpredictable future, whereas Patterson, with some reservations, looked upon the end of the conflict as related in the following anecdote: "The taxi driver taking me to the airport told me he had seen Concorde flying into Belfast earlier. 'Imagine,' he said, 'Concorde and the war over in the same day.' He paused. 'Well at least I can be sure of one of the two: I saw Concorde."' (Patterson 2006: 92). In two different voices one finds a tinge of concern and skepticism. However promising this new political opening is, its ultimate resolution is rather uncertain.

2 Lapsed Protestant provides a selection of essays and articles written by Glenn Patterson, nevertheless, my intention is to view it as a certain entity highlighting the aforesaid Northern Irish mindset.

3 Speaking of his father, Patterson draws fairly traditional family ties: "My father and I are father and son, which is to say we are close without knowing very much about one another". The thing Glenn Patterson is certain of is that his father, exhausted by the surrounding political polarization, shows no enthusiasm about "remembering"; "what's past is past" (Patterson 2006: 38) he ascertains as if unwilling, and in disagreement with his son, to reopen old wounds. 
Shackled by history and looking for possible solutions, a Northern Irish man is in an untenable position. Zygmunt Bauman in his book Society under siege describes it by saying that in a milieu which is undergoing transition and faces instability, where "the old paths" begin to fade away and the new ones are not defined yet, one "gropes in the dark" looking for a way out (2006: 112). Patterson and his characters, having faith in the definite character of the political change, stumble over the Northern Irish "siege mentality" distinguishing the two contending camps of the previous confrontational epoch. Although, on the political agenda, there are programs to "tackle ... sectarian identities", their support is fairly ineffective. The reasons for this, given by John McGarry, come down to a mismatch between intellectual elites and voting public (2004: 117). The initial presupposition that a complete mental transformation and ultimate reconciliation is within reach seems today to have been too sanguine.

Almost instinctively, Patterson indicates that no one holds the key to the most fundamental question what kind of results this political upheaval might bring. He perceives the moment of transition as a "messy and entirely human process, a story [as he says] without an end". Northern Ireland, in the above context, "cannot be said to have been done" which leads him to the conclusion that "it can take many years for a society to work through the events that have occurred in it, or even properly to understand them" (Patterson 2006: 162). Only by such inference will we understand Glenn Patterson's decision to ponder over That which was, as depicted in the book first published in 2004. This novel perfectly illustrates the impasse numerous Northern Irish people have reached, namely, whether - while facing the future - to forget and repress the past or boldly excavate the residues of bygone horrors.

The main character of That which was, Ken Avery - a Protestant minister on investigation into the mistreatment of one of his fellow-men by secret forces triggers off - regardless of his intentions - sectarian reactions on the part of his congregation as well as his associates. The fact that the protagonist happens to be a spiritual leader of a group of Protestants is not in the least unintentional. As Patterson accentuates in Lapsed Protestant, many a time has he, in different texts and documentaries, expressed his critical approach towards " ... the values and beliefs of [his] Ulster Protestant background" (Patterson 2006: 30). Currently, the writer aims at displaying the fact that after the political changeover all the contended beliefs have not perished but, paradoxically, have even been reinforced. According to him: "Protestants and Catholics may, for the most part, have stopped killing one another, but that is not to say that they are ready to live side by side. [The North] was never, by any stretch of the imagination, [integrated], but it is more profoundly divided now than at any time in its history" (2006: 62-63). 
Consequently, the opening passage of the novel indisputably shows the author's intention to [re]visit the post-Agreement Northern Irish realm and present it as still driven by the political and cultural split:

\begin{abstract}
Summertime is marching time, the time of bonfires planned and improvised and of confrontations along the sectarian interfaces. It is no news then, though it takes up column after column, that east Belfast does not imagine itself a single, harmonious community
\end{abstract}

(Patterson 2005: 3).

As opposed to an idyllic and desirable coexistence, there is only dormant hostility hidden behind a façade of tolerance. Thus the role of Ken Avery is to address the congregation in order to alert them to the fact that divisions, nurtured on political resentments, still resonate in their minds. Preaching to the crowd he quotes St Paul: "For he is our peace, who hath made both one, and hath broken the middle wall of partition between us" (Patterson 2005: 7). The wall has not been pulled down, and the minister's recognition of this basic fact is sparked by the story of a man named Larry. Larry believes that his memory has been erased by the government to make him forget about the wrongs of the past. Asked by Avery why he, a nonreligious person, comes to him for help, he cannot come up with anything but the blunt answer: "God knows" (2005: 22). This is so since Larry's story, regarded as an urban legend, is not of crucial importance. What matters here is that the Larry-figure sheds some light on the question of collective and individual memory. And that is why Ken Avery has been chosen to hear it out. He, as a minister, is in a position to make the congregation reexamine the past in order to face its demons. This is indicated in yet another biblical passage, which the minister comes across in contemplation:

\footnotetext{
And he said unto me, Son of man, I send thee to the children of Israel, to a rebellious nation that hath rebelled against me: they and their fathers have transgressed against me, even unto this very day. For they are impudent children and stiffhearted. I do send thee unto them ... Son of man, eat that thou findest ..., and go speak unto the house of Israel
}

(2005: 238-239).

Both the abovementioned transgression as well as the problem of insolence and stiff-heartedness must be highlighted by the minister. Avery lectures himself that his responsibility - one way or another - is to "... serve, but also lead [as] there [are] difficult truths about the past to be faced" (2005: 239).

Ken Avery, as Bauman would say, groping in the dark, not being able to verify the authenticity of Larry's story, cannot merely repudiate it. The only solution is to bring it into the open hoping that "... by speaking out [he] can encourage the man concerned to come forward and tell his own story" (2005: 
222). This tactic we may find analogous with the proceedings of the Truth and Reconciliation Commission commenced in South Africa after the collapse of the apartheid regime. Its central idea was to provide everyone a right to be heard. And as such it runs parallel with the concept of "recovered memory" which Foster regards as emblematic not only of Irish fiction but also of Irish history. According to Foster, "the individual's experience" is perceived as "a kind of national microcosm" (2002: xiv). Studying this microcosm, built up on an amalgamation of the personal and the collective, one is confronted with the therapeutic value of diversified narratives. The therapy, however, to be far-reaching must affect the public, namely must be taken in by common people. How, then, are Larry's and Ken Avery's narratives met? The moment East Belfast Community News announces that the minister has questioned the legitimacy of the actions taken by security forces against Larry, a ricochet of the ill-natured sense of sectarian solidarity is to be heard among the congregation:

\begin{abstract}
Avery had an instant to wonder by what force of will he was remaining steady before he heard the shout. Shame on you! ... Both Avery's hands were extended, as though he had been tricked by the perspective into thinking he could still bring pressure to bear on them. ... They were standing now, too, in the gallery. The shouts had become a chant. Shame, shame, shame
\end{abstract}

(Patterson 2005: 240).

In the end the entire congregation walks out of the church united in their lack of readiness to hear out an atypical narrative and their willingness to preserve the myth of one's self-righteousness. A follow-up to the church crisis is a radio program wherein various callers - being conservative members of this community - are rather against discussing similar problems at length. The leitmotiv of this radio dispute would be that "it was an internal matter". Also a sense of threat is noticeable when "[a] regular contributor to the programme ... wonder[s] whether ... [they] aren't in danger of looking for feds under all [their] dead" (2005: 247). This attitude characterized by a reluctance to give more critical thought to the Troubles, is indicative of - drawing on Mark Ryan's phrase - "the Loyalists' siege mentality" (1994: 137) intensified in the aftermath of the peace settlements. As a community member resentfully questions "[s]o it's all right, is it, for them ones to bomb and shoot us for thirty years, but not for anyone do a thing back?" (Patterson 2005: 92) - indicates, neither is the agreement conclusive nor in a profound way satisfactory. Their acceptance of the peace process, as it seems, is not tantamount to an eagerness for selfflagellation.

Again I will recall the South African context in order to describe reactions which bear a resemblance to those presented by Glenn Patterson. In the newly 
democratic South Africa some people tended to say: let's "forgive and forget" as not to "tear out the stitches from wounds which are only now beginning to heal" (Nicol 1995: 181, 184). However widely held such pseudo-conciliatory views were, they constituted a façade behind which lurked disagreement as to acknowledging that the burden of the past laid heavily on the shoulders of the people of the ancient regime. In the above context, Patterson's main character, Ken Avery, abides by that stance, confirming that "it is better ... to admit that the wolf is constantly with us, even when it cannot be seen and is inactive. It is better never to cease accusing" (1995: 189). Ken Avery, however, striking the right chord, does not so much aim at admonishing his congregation as at appealing to their conscience. From his perspective, though, its members in spite of the changing political climate, cultivate old traditions, widening the rift between Protestant and Catholic communities.

As the author has observed in Lapsed Protestant, Northern Irish communities are now more divided than ever. A certain renewal of feuding is detectable then, and that finds its reflection in the novel: "[t]he sectarian interfaces remained ugly. ... When a feud erupted on the Shankill Road it quickly spread into neighboring north Belfast" (Patterson 2005: 31); or "[ $t]$ hat weekend there was a bout of loyalist feuding across the river. Attempted murders, pipebombings, ransacking of homes. In east Belfast there were reports of brawls in bars, stand-offs on street corners" (2005: 96). Under the circumstances crosscommunity actions mostly end in fiasco. Likewise, in the case of Ken Avery's initiative to organize a tournament for Protestants and Catholics, it is unsurprising that his "plans had been meeting stiff resistance on both sides of the sectarian divide" (2005: 31). The minister is inculcated with a lesson that although "[c]ross-community [programs] of one kind or another were as old as the Troubles themselves ..., there were still people out there to whom it appeared to be not-very-good news" (2005: 33-34). And it should be Avery who has a right to be disheartened from taking part in such projects since he suffered a personal loss when Joanna - his first true love - had been murdered due to someone's "dislike of cross-community work" (2005: 33). But Avery cannot relinquish the struggle, less so with the following thought lingering on in his head: "[is] there anything the Church can do to wean [people] from violence?" (2005: 50). This question is particularly vital in relation to young minds. Either they are to be brought up on principles which esteem the dignity of others or, nurtured on the old beliefs, they will contribute to the prolongation of the decades-long strife.

4 It is Mike Nicol who in his book The waiting country reveals the hollowness as well as insincerity of numerous catchphrases, most often uttered by various policy-makers, which raised to avoid "painful confrontations, lies, fear and even violence" call for "build[ing] a nation" and "allow[ing] for a healing process" (1995: 184). 
Avery, not wanting the latter to happen, must respond. For that very reason, the minister during "the annual Boys' Brigade enrolment service" - thus a service organized for teenagers with "drill experience" whose predecessors "supplied half the officers for the Ulster Defense Army" - is asking them to consider their motto:

Sure and Steadfast. How many times in their BB careers had they heard those words? Sure and Steadfast. He wasn't going to patronize them to put their hands up if they knew what they meant. ... But had they, he wondered, stopped to think how those words had come down to us? Sure, from the Latin secures, by way of Old French. Steadfast, from the Old English stede, place, and faeste, like the German fest, fixed. These were not words that were born to be together. For years and years - centuries - their families weren't even on speaking terms

(Patterson 2005: 88).

Avery's standpoint appears to promote an appreciation of a cultural multilayeredness; seems to endorse Northern Irish identity as established on paired differences. His view goes along with a vision of Peter Mandelson - Secretary of State for Northern Ireland [1999-2001] - who would like to see “... a vibrant, creative society capable of great tolerance and inclusivity ...; a society which celebrates its diversity; a society in which Orange and Gaelic can live side by side in mutual respect" (2007: 121).

But this society is still far away from the abovementioned ideal. Its insular mind-set does not allow individuals to cross the zone-line behind which the sectarian sense of righteousness is to be undermined. And so the celebration of diversity has more to do with an official optimism than with the present-reality which - as defined by Harvey Cox - is reduced to the following conviction: "Peace as ... wholeness, reconciliation, atonement ... [t] $]$ oo much, too soon, to expect" (2007: 172). A more preferable, and in fact adopted posture, is the one marked by a deliberately opted-for amnesia. Of the past haunting and painful memories one would, undoubtedly, like to forget instead of stirring them up. As Ken Avery learns " $[t]$ here are a lot of damaged people walking about the city [and] it ha[s] been the business of many ... to grow as far away from [upsetting recollections] as they could manage". The Troubles made them go through an ordeal which led to "trauma [which eventually] could cause [such] problems [as] amnesia" (Patterson 2005: 66-67). Nevertheless, there is no running away either from one's pain or one's guilt. Remembering, however, should not be a result of cultural, political or religious bias unless one wants to remain faithful to "... the solidarity of remembered victimhood" (Arthur 2007: 150) and fall victim of the aforementioned "siege mentality".

In no way is the loss of memory able to end the Northern Irish conflict; therefore, Ken Avery's desperate crusade has as its addressee not Larry, but 
actually the congregation to whom a memory sermon has been given. His people must realize, as Paul Arthur claims, that "war[s] creat[ing] fear" result in a lack of dialogue; yet one "cannot reconcile with the living if one cannot reconcile with the dead" (2007: 150). The Protestant minister, a victim himself, conscious of this basic truth, decides to consider the past trauma individually, in his own conscience: "Did he [Avery] really want to go on with this? He asked himself, though, what the alternative was" (Patterson 2005: 57). This bold step of his leads him to an appreciation of "[a] book ..., a chronology, with details of all the people killed in the thirty-three years since 1966" (2005: 57). The thing is where such a positive reception comes from? Avery, as if detached from the contemporary conflict, reads the book as "a work of great integrity and restraint, entirely without sensationalism or sentimentality, a labour of the authors' true love for their fellow Northern Irish men and women" (2005: 56). Patterson suggests that people in Northern Ireland, in general, have fallen victim to the war; that crimes and guilt do not lay just at the other door; and that responsibilities must be recognized and the dead must be mutually commemorated on both sides irrespective of political likes or dislikes.

Everyone, individually, is obliged to substantiate the presence of the past and the dead they way Ken Avery does. In his dream he envisions not only his beloved Joanna but also others who desperately want to partake of "tearful reunion":

\begin{abstract}
Avery dreamt he was in a bus station waiting for Joanna. He knew in the dream that she was dead, but thanks to negotiations, which he understood without having to articulate, the Troubles' dead were being allowed home for the weekend ... A bus pulled in ... [t] $]$ he doors opened and the people in the waiting room moved forward, waving, calling names, holding their photographs ... above their heads. ... The dead were materializing as though from contact with the bus-station air. They looked ... weary, but full of stories
\end{abstract}

(2005: 107).

Only when all such stories have been taken heed of, as it seems by the public, is the aforesaid reunion likely to happen. And however painful it is to hear such accounts, and however unwilling men are to reflect on them, the Northern Irish must endure it with attentiveness and, as suggested by the Dalai Lama, patience. "Patience [according to him] is the awareness that enlightenment is a long, long pursuit" (2005: 119). At the end of this road one expects to find forgiveness and understanding, yet based on an impartial disclosure of past traumas. Understanding, in the above context, appears even more important than forgiveness because, as it usually happens, it comes into being after having set aside political sympathies or cultural partialities. That kind of detachment facilitates a more critical - objective - view of raw historical material. 
Ken Avery, in the above context, turns out to be a good exemplification of a non-sectarian approach. Reconsidering the Derry massacre, he comes up with a more balanced, nonaligned opinion: "Tomorrow, the thirteenth day of the eleventh month, the inquiry was due to resume in Derry into the events of Bloody Sunday ... . Avery had no difficulty accepting that the army had been culpable there, though he didn't believe you needed to see premeditation in its murderous actions" (Patterson 2005: 149). The minister, along with his friends, realizes that "what was important was to get everything into the open. However uncomfortable to begin with, it was safer out there in the long run" (2005: 216). Everyone is invited to take that impartial journey out of the darkness into the spotlight, no matter how long and painful this process is to be.

Overall, a disconcerting question, running through Lapsed Protestant and That which was, is by far discernible, namely, has the Northern Irish war - after a long wait - ended. Patterson is rather pessimistic as the deeply ingrained nightmare of the past does not allow to make the mental divide ineffective. The author, however, considers it urgent to leave behind the prison-house of traumatic memories so as to find reconciliation, yet he knows it cannot be accomplished on the wrong premise that it is sufficient to forget and press forward. Ken Avery, the main protagonist, an epitome of the stance adopted by Patterson understands that memory is hardly likely to be neutral and most often is eclipsed by political coloring. Still, in order to sidestep a permanent warfare, only this time less deadly, the Northern Irish need a genuine dialogic interchange based on a more balanced politics of memory. Therefore, Avery, as well as the author himself, defying the urge to constantly hark back on every painful event and the desire to remember nothing, thus obliterating the uncomfortable past, opt for taking a middle course, that is leaving the entrenched positions with the intention of meeting half a way and remembering to understand.

\title{
REFERENCES
}

\section{PRIMARY SOURCES}

\author{
Patterson, Glenn \\ 2005 That which was. London: Penguin Books. \\ 2006 Lapsed Protestant. Dublin: New Island.
}

\section{SECONDARY SOURCES}

\author{
Arthur, Paul \\ 2007 "Conflict, memory and reconciliation", in: Marianne Elliott (ed.), 147-156.
}


Bauman, Zygmunt

2006 Społeczeństwo w stanie oblężenia [Society under siege]. Warszawa: Wydawnictwo Sic.

Benjamin, Walter

1996 "O pojęciu historii" [“On the notion of history”], in: Hubert Orłowski (ed.), 413-425.

Cox, Harvey

2007 "Keeping going: Beyond Good Friday", in: Marianne Elliott (ed.), 157-174.

Elliott, Marianne (ed.)

2007 The long road to peace in Northern Ireland. Liverpool: University Press.

Foster, Robert Fitzroy

2002 Telling tales and making it up in Ireland. Oxford: University Press.

Gordimer, Nadine

2000 Living in hope and history. London: Bloomsbury.

Kennedy-Andrews, Edward

2003 (De-)constructing the North. Dublin: Four Courts Press.

Kiberd, Declan - Edna Longley (eds.)

2001 Multi-Culturalism: The view from the two Irelands. Cork: University Press.

Laird, Nick

2006 Utterly monkey. (Interview.) London - New York: Harper Perennial.

Longley, Edna

2001 "Strangers in their own country: Multi-Culturalism in Ireland", in: Declan Kiberd Edna Longley (eds.), 1-45.

Mandelson, Peter

2007 "The Good Friday Agreement: A vision for a new order in Northern Ireland", in: Marianne Elliott (ed.), 119-123.

McGarry, John (ed.)

2004 Northern Ireland and the divided world. Oxford: University Press.

2004 "Northern Ireland, civic nationalism, and the Good Friday Agreement", in: John McGarry (ed.), 109-136.

Nicol, Mike

1995 The waiting country. A South African witness. London: Victor Gollancz.

Orłowski, Hubert (ed.)

1996 Aniot historii [Angel of history]. Poznań: Poznańska Biblioteka Niemiecka.

Ryan, Mark

1994 War and peace in Ireland. London - Boulder, Col.: Pluto Press.

\section{INTERNET SOURCES}

Hogg, Clare Dwyer

2004 "Glenn Patterson interviewed by C. D. Hogg", available at http://www.independent. co.uk/arts-entertainment/books/features/glenn-patterson-alternative-ulster-567608. html (date of access: 23 November 2008). 